\title{
Lymphocyte sensitization to basic protein of brain in multiple sclerosis and other neurological diseases
}

\author{
E. A. CASPARY AND E. J. FIELD \\ From the Medical Research Council, Demyelinating Diseases Unit, and Institute of Pathology, \\ Newcastle General Hospital, Newcastle upon Tyne
}

SYNOPSIS The number of lymphocytes in the blood sensitized to encephalitogenic factor (EF) is less in multiple sclerosis than it is in general paralysis of the insane. The number appears related to the extent of parenchymatous destruction. The study offers no support for the view that lymphocyte sensitization to EF is of pathogenetic significance in multiple sclerosis.

While the aetiology and pathogenetic mechanism of multiple sclerosis (MS) remain obscure, there is widespread belief that immunological reaction, especially of delayed hypersensitivity type involving lymphocyte sensitization to encephalitogenic factor (EF), plays an important role at least in the maintenance and recurrent activity of the disease. It therefore seemed worthwhile finding out if there were special sensitization of MS lymphocytes to EF in excess of that present in other neurological diseases with comparable brain destruction but believed to be without immunological pathogenesis. To measure lymphocyte sensitization, the recently introduced macrophage electrophoretic migration (MEM) test was used (Field and Caspary, 1970, 1971; Caspary and Field, 1971).

\section{METHODS}

Altogether 12 patients suffering from multiple sclerosis (10 in an acute phase; two quiescent); seven patients with syphilitic dementia paralytica, and 16 with other neurological diseases (OND) (detailed below) have been studied. Large numbers of normal control subjects have been reported in previous studies.

Lymphocytes were prepared from about $15 \mathrm{ml}$ venous blood by the carbonyl iron methyl cellulose method of Coulson and Chalmers (1967) as modified by Hughes and Caspary (1970). Normal guinea-pig macrophages were raised by intraperitoneal injection of liquid paraffin and harvesting after six to 10 days as described by Field and Caspary (1971). The lymphocytes were tested for sensitization to EF, a basic protein prepared from normal brain by defatting with a chloroform-methanol mixture followed by acid extraction (Caspary and Field, 1965). This material when purified by column chromatography is capable of producing experimental allergic encephalomyelitis (EAE) in guinea-pigs after injection of doses as low as $1 \mu \mathrm{g}$ (with Freund's complete adjuvant) and is the putative antigen at work in multiple sclerosis.

Since previous work had shown that lymphocytes from MS and OND are sensitized to EF (Caspary and Field, 1970), an attempt was made to titre out this lymphocyte sensitization in different neuro-

TABLE 1

LYMPHOCYTE SENSITIZATION TO EF IN PATIENTS WITH MULTIPLE SCLEROSIS

\begin{tabular}{|c|c|c|c|c|c|c|c|}
\hline \multirow[t]{2}{*}{ Patient } & \multirow{2}{*}{$\begin{array}{l}\text { Age } \\
(y r)\end{array}$} & \multirow[t]{2}{*}{ Sex } & \multicolumn{5}{|c|}{ Millions of lymphocytes } \\
\hline & & & $0 \cdot 3$ & $0 \cdot 2$ & $0 \cdot 1$ & 0.05 & $0 \cdot 0 I$ \\
\hline \multicolumn{8}{|c|}{ Acute } \\
\hline S.W. & 46 & $\mathbf{F}$ & - & $15 \cdot 9$ & $15 \cdot 8$ & $8 \cdot 1$ & $1 \cdot 1$ \\
\hline G.P. & 18 & $\mathbf{F}$ & $13 \cdot 5$ & $13 \cdot 6$ & $13 \cdot 2$ & $2 \cdot 3$ & $2 \cdot 3$ \\
\hline J.O. & 51 & $\mathbf{F}$ & - & $14 \cdot 2$ & $14 \cdot 3$ & $4 \cdot 1$ & $1 \cdot 6$ \\
\hline D.S. & 48 & $\mathbf{F}$ & 一 & $15 \cdot 5$ & $15 \cdot 3$ & $1 \cdot 8$ & - \\
\hline M.S. & 32 & $\mathbf{M}$ & - & $15 \cdot 5$ & $15 \cdot 2$ & $5 \cdot 7$ & 一 \\
\hline P.T. & 34 & $\mathbf{M}$ & - & $15 \cdot 6$ & $15 \cdot 5$ & $6 \cdot 3$ & - \\
\hline A.M. & 55 & $\mathbf{F}$ & - & $16 \cdot 1$ & $16 \cdot 2$ & $6 \cdot 7$ & - \\
\hline I.W. & 39 & $\mathbf{F}$ & 一 & $15 \cdot 1$ & 15.0 & $4 \cdot 8$ & 0.8 \\
\hline J.B. & 38 & $\mathbf{M}$ & - & $14 \cdot 2$ & $14 \cdot 2$ & $4 \cdot 1$ & 0.5 \\
\hline M.T. & 28 & $\mathbf{M}$ & - & $15 \cdot 9$ & $15 \cdot 6$ & $6 \cdot 0$ & $1 \cdot 2$ \\
\hline \multicolumn{8}{|c|}{ Quiescent } \\
\hline C.H. & 52 & $\mathbf{M}$ & $15 \cdot 3$ & $15 \cdot 5$ & $15 \cdot 5$ & $7 \cdot 2$ & 19 \\
\hline W.G. & 48 & $\mathbf{M}$ & 160 & $16 \cdot 3$ & $16 \cdot 2$ & $3 \cdot 9$ & $1 \cdot 3$ \\
\hline
\end{tabular}


logical diseases. In the standard MEM test 0.5 million lymphocytes are allowed to interact with $100 \mu \mathrm{g}$ $\mathrm{EF}(33 \mu \mathrm{g} / \mathrm{ml})$ in the presence of $10^{7}$ irradiated normal guinea-pig peritoneal exudate cells as described in detail by Caspary and Field (1971) with an experimental protocol in extenso. It was felt that there might be a lesser number of EF-sensitized lymphocytes contained in a half million blood cell sample in some nervous diseases than in others, and if such lymphocytes were an important pathogenetic factor in MS it might be expected that more would be present in this disease than in OND. Since preliminary experiments during the development of the test had shown that it remained positive even with $0 \cdot 1 \times 10^{6}$ cells, tests were carried out using $0 \cdot 3,0 \cdot 2$, $0.1,0.05$, and 0.01 million human lymphocytes instead of the standard 0.5 million.

In carrying out a test $100 \mu \mathrm{g}$ of EF was added to the appropriate number of lymphocytes together with $10^{7}$ irradiated macrophages in a total volume of $3.0 \mathrm{ml}$ and incubated at $20^{\circ} \mathrm{C}$ for 90 minutes. Macrophage migration time was then measured. If $t_{c}=$ migration when no antigen was present; $t_{e}=$ time when EF present; then $t_{e}>t_{c}$ and $\left(t_{e}-t_{c} / t_{c}\right) \times 100$ is a measure of the reaction between the lymphocytes and EF. All measurements are, of course, carried out 'blind' on randomly scrambled specimens.

\section{RESULTS}

The results are presented in Tables 1, 2, and 3, where the figures are percentage macrophage slowings as calculated above.
TABLE 2

LYMPHOCYTE SENSITIZATION TO EF IN PATIENTS WITH DEMENTIA PARALYTICA

\begin{tabular}{lcccccccc}
\hline Patiert & $\begin{array}{l}\text { Age } \\
(y r)\end{array}$ & Sex & \multicolumn{5}{c}{ Millions of lymphocytes } \\
\cline { 3 - 8 } & & & 0.2 & 0.1 & 0.05 & 0.025 & 0.01 \\
\hline J.I. & 69 & F & 16.5 & 16.1 & 10.1 & - & 2.0 \\
D.W. & 58 & F & 15.6 & 15.8 & 15.7 & - & 1.7 \\
W.T. & 56 & M & 14.6 & 14.3 & 12.4 & 2.5 & 2.5 \\
T.N. & 75 & M & 16.7 & 15.0 & 15.6 & 5.6 & 1.3 \\
R.R. & 50 & M & 149 & 143 & 104 & 19 & 1.3 \\
J.T. & 71 & M & 15.1 & 15.7 & 10.4 & 2.2 & 1.3 \\
W.J. & 77 & M & 16.4 & 16.3 & 15.6 & 6.1 & 1.3 \\
& & & & & & & & \\
\hline
\end{tabular}

In all cases there is very little difference in the $\vec{\circ}$ measurements made when $0 \cdot 3,0 \cdot 2$, or $0 \cdot 1$ million $\vec{\omega}$ cells are used, but differences emerge at the $0.05^{\circ}$ million level. Here results with dementia paralytica are distinctly higher than with $\mathrm{MS}(\mathrm{P}<\dot{\omega}$ $0.001)$. Indeed, in the former group three patients. gave significantly positive results even wifi 0.025 million cells and one even with 0.01 milliog. Among the OND group there were obvions differences, patients with subacute sclerosing panencephalitis, glioma, and Creutzfeldt-Jakob disease having higher sensitization than others, and indeed higher than that found in MS. Among normal individuals (unexposed to EF) the figure never exceeds $5 \%$ (Field and Caspary, 1970; Caspary and Field, 1971).

TABLE 3

LYMPHOCYTE SENSITIZATION TO EF IN PATIENTS WITH OTHER NEUROLOGICAL DISEASES (OND)

\begin{tabular}{|c|c|c|c|c|c|c|c|c|}
\hline \multirow[t]{2}{*}{ Patient } & \multirow{2}{*}{$\begin{array}{l}\text { Age } \\
(y r)\end{array}$} & \multirow[t]{2}{*}{ Sex } & \multicolumn{5}{|c|}{ Millions of lymphocytes } & \multirow[t]{2}{*}{ Diagnosis } \\
\hline & & & $0 \cdot 2$ & $0 \cdot 1$ & 0.05 & 0.025 & 0.01 & \\
\hline B.H. & 12 & $\mathbf{F}$ & 124 & $12 \cdot 4$ & $12 \cdot 4$ & $2 \cdot 4$ & - & Subacute sclerosing panencephalitis \\
\hline J.D. & 39 & $\mathbf{M}$ & $15 \cdot 1$ & $15 \cdot 2$ & $9 \cdot 3$ & $1 \cdot 0$ & - & Glioma \\
\hline J.B. & 52 & $\mathbf{M}$ & $16 \cdot 0$ & $16 \cdot 0$ & $10 \cdot 9$ & 1.9 & - & Herpes encephalitis \\
\hline A.D. & 52 & $\mathbf{F}$ & $13 \cdot 5$ & $13 \cdot 4$ & $3 \cdot 2$ & $1 \cdot 1$ & - & Subarachnoid haemorrhage \\
\hline D.K. & 53 & $\mathbf{M}$ & $15 \cdot 9$ & $15 \cdot 8$ & $11 \cdot 3$ & $1 \cdot 8$ & $1 \cdot 2$ & Jakob-Creutzfeldt \\
\hline J.W. & 54 & $\mathbf{F}$ & $16 \cdot 1$ & $15 \cdot 8$ & $8 \cdot 2$ & $1 \cdot 5$ & - & Glioma \\
\hline E.B. & 54 & $\mathbf{F}$ & $15 \cdot 9$ & $15 \cdot 7$ & $10 \cdot 8$ & 0.7 & - & Glioma \\
\hline M.D. & 17 & $\mathbf{M}$ & $14 \cdot 1$ & $14 \cdot 1$ & $2 \cdot 9$ & $1 \cdot 0$ & - & Epilepsy \\
\hline E.B. & 42 & $\mathbf{F}$ & $14 \cdot 2$ & $13 \cdot 9$ & $1 \cdot 2$ & 一 & - & Lumbar canal stenosis \\
\hline E.T. & 48 & $\mathrm{M}$ & $15 \cdot \overline{7}$ & $15 \cdot 6$ & $7 \cdot 0$ & 0.9 & - & Multiple strokes \\
\hline G.B. & 52 & $\mathbf{M}$ & $14 \cdot 8$ & $14 \cdot 6$ & $4 \cdot 1$ & $1 \cdot 3$ & - & Cerebrovascular disease \\
\hline T.B. & 53 & M & $14 \cdot 8$ & $14 \cdot 6$ & $4 \cdot 7$ & 0.8 & - & Lumbar disc, cord compression \\
\hline M.C. & 54 & $\mathbf{F}$ & $15 \cdot 4$ & $15 \cdot 6$ & $5 \cdot 2$ & $1 \cdot 0$ & - & Syringomyelia \\
\hline F.McD. & 54 & $\mathbf{M}$ & $14 \cdot 9$ & $14 \cdot 8$ & $5 \cdot 2$ & $1 \cdot 8$ & - & Lumbar disc, cord compression \\
\hline G.S. & 64 & $\mathbf{M}$ & $15 \cdot 8$ & $15 \cdot 4$ & $2 \cdot \overline{3}$ & 一 & $1 \cdot 5$ & Dementia, motor neurone disease \\
\hline C.S. & 74 & $\mathbf{F}$ & $14 \cdot 0$ & $14 \cdot 0$ & $2 \cdot 9$ & $1 \cdot 0$ & - & Stroke \\
\hline
\end{tabular}




\section{DISCUSSION}

The high value maintained when the number of lymphocytes was reduced to $0 \cdot 1$ million confirms a previous finding during a study of the kinetics of the MEM test (Carnegie et al., 1973) when it was established that the percentage slowing response curve was $\mathrm{S}$ shaped in relation to the number of lymphocytes used and that in working with 0.5 million cells the response was on the plateau. As the number of cells used in the test is reduced the result slips off the normal working plateau onto the rapidly descending part of the S-shaped curve as the number of sensitized cells becomes inadequate to give a maximal (plateau) response.

It is clear that there must be a lesser number of sensitized lymphocytes in the blood of MS patients than there is in the circulation of patients with dementia paralytica. Among the OND group it is those in whom there is reason to believe there is greatest brain destruction who have highest figures. In general, the results indicate that the degree of lymphocyte sensitization relates to the degree of nervous parenchymal damage. If lymphocyte sensitization were a primary pathogenetic factor in MS, it might be expected that the number of EF sensitized lymphocytes would be greater than in other diseases for which there is no postulated immunological basis-for example, glioma, CreutzfeldtJakob disease. The case of syphilitic dementia paralytica is somewhat equivocal, since there are some who have postulated that it may, in fact, be some form of immune destruction of the brain though this has usually been supposed to involve the treponeme or its products as antigen.
Most of the MS patients studied were in an acute phase of the disease. It is noticeable that their response was not higher than in the patients with quiescent disease.

The present work thus offers no support for the view that lymphocyte sensitization to $\mathrm{EF}$ may be the pathogenetic basis for the development of MS. A longitudinal study of MS with reference to the number of sensitized lymphocytes and acute attacks is in progress. Preliminary results indicate, not unexpectedly, that the cells increase after an acute episode.

\section{REFERENCES}

Carnegie, P. R., Caspary, E. A., Dickinson, J. P., and Field, E. J. (1973). The macrophage electrophoretic migration (MEM) test for lymphocyte sensitization. Clinical and Experimental Immunology, 14, 37-45.

Caspary, E. A., and Field, E. J. (1965). An encephalitogenic protein of human origin; some chemical and biological properties. Annals of the New York Academy of Science, 122, 182-198.

Caspary, E. A., and Field, E. J. (1970). Sensitization of blood lymphocytes to possible antigens in neurological disease. European Neurology, 4, 257-266.

Caspary, E. A., and Field, E. J. (1971). Specific lymphocyte sensitization in cancer: is there a common antigen in human malignant neoplasia? British Medical Journal, 2, 613-617.

Coulson, A. S., and Chalmers, D. G. (1967). Response of human blood lymphocytes to tuberculin PPD in tissue culture. Immunology, 12, 417-429.

Field, E. J., and Caspary, E. A. (1970). Lymphocyte sensitisation: an in-vitro test for cancer. Lancet, 2, 1337-1341.

Field, E. J., and Caspary, E. A. (1971). Demonstration of sensitized lymphocytes in blood. Journal of Clinical Pathology, 24, 179-181.

Hughes, D., and Caspary, E. A. (1970). Lymphocyte transformation in vitro measured by tritiated thymidine uptake. 1. International Archives of Allergy, 37, 506-531. 